\title{
ANALISIS YURIDIS POLITIK HUKUM TATA NEGARA (Suatu Kajian Tentang Pancasila dan Kebhinnekaan Sebagai Kekuatan Negara Kesatuan Republik Indonesia)
}

\author{
Rudi Santoso \\ Universitas Islam Negeri Raden Intan Lampung \\ Email: rudisantoso@radenintan.ac.id \\ Agus Hermanto \\ Universitas Islam Negeri Raden Intan Lampung \\ Email: agushermanto@radenintan.ac.id
}

\begin{abstract}
The many threats of radicalization in the middle of society, the demonstration actions that often ask for the application of certain ideologies within the state of Indonesia, the conflict between ethnic, religious, racial and custom makes the tranquility of Bhinneka Tunggal Ika society to be threatened and the erosion of values Pancasila among the younger generation that endanger the survival of the Indonesian nation. The problem of this research is how the Political Law of the State in the concept and context of Pancasila and Diversity in defending the Unitary State of the Republic of Indonesia and How the Strength of the Unitary State of the Republic of Indonesia Based on Pancasila and Unity in Diversity and How Radicalism and Threat Against the Unity of the Unitary Republic State Indonesia.This research uses normative juridical approach method, then data collection procedure is done by literature study, data processing procedure is done by data classification, data inventory, systematization of data, and data analysis is done by qualitative method.The result of the research, the politics of constitutional law in the concept and context of Pancasila and Diversity in defending the Unitary State of the Republic of Indonesia in accordance with the nationalist ideology set forth in the 1945 Constitution, the power of the Unitary State of the Republic of Indonesia based on Pancasila and Diversity is based on the strength of local wisdom from all elements of the nation Indonesia, radicalism and threats to the unity of the Unitary State of the Republic of Indonesia through the strengthening of national insight among the younger generation and the people and leaders of the nation and state apparatus.Suggestion in this research, expected to government can reinforce study of nationality and education of Pancasila and Diversity, to Indonesian society.
\end{abstract}

Keywords: Pancasila, Unity in Diversity, Radicalism.

\section{A. Pendahuluan}

Bangsa Indonesia atau Negara Kesatuan Republik Indonesia (NKRI) sebagaimana yang dijelaskan Pasal 1 ayat (1) berbunyi bahwa "Negara Indonesia merupakan Negara Kesatuan, yang berbentuk Republik", jo Pasal 37 ayat (5) sesudah amandemen ke- IV berbunyi bahwa "Khusus mengenai format atau bentuk Negara Kesatuan Republik Indonesia tidak dapat dilakukan perubahan" UndangUndang Dasar Republik Indonesia Tahun 1945 (selanjutnya disingkat UUD 1945). Negara Indonesia adalah negara yang mempunyai potensi kekayaan sumber daya 
alam dan sumber daya manusia yang terdiri atas banyak suku, agama, ras dan adatistiadat.

Pembukaan UUD 1945 alinea ke-4 berbunyi "Kemudian daripada itu untuk membentuk suatu Pemerintah Negara Indonesia yang melindungi segenap bangsa Indonesia dan seluruh tumpah darah Indonesia dan untuk memajukan kesejahteraan umum, mencerdaskan kehidupan bangsa, dan ikut melaksanakan ketertiban dunia yang berdasarkan kemerdekaan, perdamaian abadi dan keadilan sosial, maka disusunlah kemerdekaan kebangsaan Indonesia itu dalam suatu Undang-Undang Dasar Negara Indonesia, yang terbentuk dalam suatu susunan Negara Republik Indonesia yang berkedaulatan rakyat dengan berdasar kepada Ketuhanan Yang Maha Esa, Kemanusiaan yang adil dan beradab, Persatuan Indonesia dan Kerakyatan yang dipimpin oleh hikmat kebijaksanaan dalam Permusyawaratan/Perwakilan, serta dengan mewujudkan suatu Keadilan sosial bagi seluruh rakyat Indonesia."

Pembukaan UUD 1945 alinea ke-4 diatas apabila diuraikan, adalah sebagai berikut:

1. Pancasila adalah dasar pandangan hidup negara (asas kerohanian negara), falsafah dan pandangan hidup hidup;

2. Diatas basic (dasar) tersebut berdirilah negara Indonesia, dengan asas politik negara (kenegaraan) yakni berupa Republik yang berkedaulatan rakyat;

3. Kedua-duanya menjadi basis penyelenggaraan kebebasan kebangsaan Indonesia, yakni pelaksanaan dan penyelenggaraan negara sebagaimana tertera dalam hukum positif Indonesia, termuat dalam UUD 1945;

4. Selanjutnya diatas UUD 1945 maka berdirilah format susunan pemerintahan dan keseluruhan ketentuan hukum positif lainnya, yang merangkum segenap bangsa Indonesia dalam sebuah kesatuan hidup bareng yang berasas kekeluargaan;

5. Segala sesuatu yang dilafalkan diatas ialah demi tercapainya sebuah tujuan bersama, yaitu destinasi bangsa Indonesia dalam bernegara tersebut, yakni kebahagiaan bersama, baik jasmaniah maupun rohaniah serta tauhiyah.

Bangsa Indonesia dalam membentuk dan menyusun suatu negara bukan merupakan proses kausalitas manusia sebagai makhluk pribadi yang bebas, tetapi suatu proses kehendak bareng untuk menyusun suatu bangsa dalam wadah Negara Kesatuan Republik Indonesia, dalam definisi inilah maka negara Indonesia pada hakikatnya adalah suatu negara kebangsaan dan bukannya negara liberal. ${ }^{1}$

Bangsa Indonesia berpancasila dalam 3 (tiga) asas atau Tri Prakara (menurut istilah notonagoro), yang perinciannya sebagai berikut:

1. Bahwa unsur-unsur Pancasila sebelum disahkan secara yuridis menjadi pandangan hidup negara, sudah dipunyai oleh bangsa Indonesia sebagai asasasas dalam adat-istiadat dan kebudayaan dalam makna luas (Pancasila Asas Kebudayaan);

2. Demikian juga unsur-unsur Pancasila sudah ada pada bangsa Indonesia sebagai asas-asas dalam agama-agama atau religious (Pancasila Asas Religius);

1Kaelan, Pendidikan Pancasila, (Paradigma: Yogyakarta, 2014), h. 263. 
3. Unsur-unsur tersebut lantas diolah, dibicarakan dan dirumuskan secara cermat oleh semua pendiri negara dalam sidang-sidang BPUPK, Panitia "sembilan", sesudah Indonesia merdeka oleh PPKI sebagai dasar pandangan hidup negara Indonesia dan terwujudlah Pancasila sebagai asas kenegaraan (Pancasila Asas Kenegaraan).

Pancasila sebagai konsep dasar negara Indonesia, kesetaraan dan toleransi adalah wujud dari demokrasi, karena itu cukup beralasan jika Nurcholish Madjid menegaskan bahwa modal utama mewujudkan demokrasi di Indonesia ialah Pancasila, sedangkan tempat tinggal demokrasi ialah masyarakat madani yang didalamnya ada heterogenitas masyarakat. Berdasarkan keterangan dari Jimly Asshiddiqie, dalam menilai Pancasila, ada sejumlah uraian yakni:

1. Pancasila tidak dijadikan sebagai perangkat penguasa, dimana penguasa memonopoli pemaknaan dan pengartian Pancasila yang dipakai untuk kepentingan kekuasaan;

2. Konsep Pancasila sebagai ideologi harus sungguh-sungguh diwujudkan dengan kata lain bukan melulu dalam wacana saja;

3. Adanya kesatuan antara hati dan pengamalan. ${ }^{2}$

Kesepakatan yang menjamin dan memastikan tegaknya konstitusionalisme negara moderen pada proses reformasi guna mewujudkan demokrasi, pada lazimnya bersandar pada 3 (tiga) unsur kesepakatan, yaitu:

1. Kesepakatan mengenai tujuan dan cita-cita bersama (the general goal of society or general acceptance of the same philosophy of government);

2. Kesepakatan mengenai the rule of law sebagai landasan pemerintahan atau penyelenggaraan negara (the basis of government);

3. Kesepakatan tentang format institusi-institusi dan formalitas ketatanegaraan (the form of institutions and procedures). ${ }^{3}$

Kekhawatiran pemerintah tentang adanya radikalisme di tengah masyarakat, dengan adanya gerakan-gerakan yang ingin mengganti ideologi Pancasila ke ideologi lainnya membuat kekhawatiran terhadap kondisi kebangsaan yang mengarah kepada intoleransi dan disintegrasi ditengah masyarakat, sehingga pemerintah kembali membuat tindakan dengan menerbitkan Peraturan Presiden (Perpres) Nomor 54 Tahun 2017 tentang Unit Kerja Presiden Pembinaan Ideologi, yang bertujuan untuk membangun kembali nilai-nilai Pancasila didalam masyarakat. Pemerintah juga melakukan penertiban bagi kelompok-kelompok masyarakat yang memiliki jumlah anggota yang tidak sedikit untuk memperkuat nilai-nilai Pancasila dan Bhinneka Tunggal Ika, dengan mengeluarkan Peraturan Pemerintah Pengganti Undang-Undang (selanjutnya disingkat Perppu) Nomor 2 Tahun 2017 mengenai Perubahan Atas Undang-Undang Nomor 17 Tahun 2013 mengenai Organisasi Kemasyarakatan.

Berdasarkan uraian tersebut diatas, penelitian ini secara yuridis normatif mengkaji sepurat"Analisis Yuridis Politik Hukum Tata Negara (Suatu Kajian Tentang Pancasila dan Kebhinnekaan Sebagai Kekuatan Negara Kesatuan Republik Indonesia).

2Kaelan, Pendidikan Pancasila.., h. 275.

3Ibid, h. 105. 


\section{B. Pembahasan}

\section{B.1. Pengertian, Tujuan Dan Fungsi NKRI}

\section{B.1.1. Negara Kesatuan Republik Indonesia}

Berdasarkan keterangan Harold J. Laski, bahwa negara ialah suatu masyarakat yang diintegrasikan karena mempunyai wewenang yang mempunyai sifat atau karaketer memaksa yang secara saha lebih tinggi daripada individu-individu atau kelompok-kelompok yang terdapat dalam negara tersebut, untuk menjangkau tujuan bersama. Masyarakat dapat disebutkan sebagai suatu negara bila cara hidup yang meesti ditaati baik oleh pribadi maupun oleh kelompok ditentukan oleh sebuah aturan yang mempunyai sifat mengikat dan memaksa. Berdasarkan keterangan dari Robert MacIver negara ialah asosiasi yang mengadakan ketertiban didalam sebuah masyarakat, dalam wilayah menurut sistem hukum yang diadakan oleh pemerintah dan untuk itu diberi kekuasaan memaksa. Unsur negara terdiri atas wilayah, masyarakat atau rakyat, pemerintahan dan kedaulatan. ${ }^{4}$

Hal ini sesuai rumusan Pembukaan UUD 1945 Alinea ke-4: "Kemudian daripada itu untuk membentuk suatu pemerintahan negara Indonesia yang melindungi segenap bangsa Indonesia dan seluruh tumpah darah Indonesia dan untuk memajukan kesejahteraan umum, mencerdaskan kehidupan bangsa, dan ikut melaksanakan ketertiban dunia yang berdasarkan kemerdekaan, perdamaian abadi, dan keadilan sosial, maka disusunlah kemerdekaan kebangsaan Indonesia itu dalam suatu Undang-Undang Dasar Negara Indonesia, yang terbentuk dalam suatu susunan Negara Republik Indonesia yang berkedaulatan rakyat dengan berdasar kepada Ketuhanan Yang Maha Esa, kemanusiaan yang adil dan beradab, persatuan Indonesia, dan kerakyatan yang dipimpin oleh hikmat kebijaksanaan dalam permusyawaratan/perwakilan, serta dengan mewujudkan suatu keadilan sosial bagi seluruh rakyat Indonesia".

Kearifan lokal (local wisdom), yang terkristalisasi menjadi sistem nilai yang disebut Pancasila, dalam upaya membentuk membentuk suatu persekutuan hidup atau negara, maka Indonesia mendasarkan pada pandangan hidup yang telah dimilikinya. Pendirian negara yang memiliki karakteristik agama, ras, suku, dan adat-istiadat, maka bangsa ini mendasarkan pendiriannya negaranya berdasarkan filsafat pancasila, yaitu negara persatuan, negara kebangsaan serta negara yang bersifat integralistik.

\section{B.1.2. Tujuan dan Fungsi Negara Kesatuan Republik Indonesia}

Tujuan Negara kesatuan Republik Indonesia, sesuai dengan pembukaan UUD 1945, adalah sebagai berikut:

1. Memajukan kesejahteraan umum;

2. Melaksanakan ketertiban dunia berdasarkan kemerdekaan, perdamaian abadi dan keadilan sosial;

3. Melindungi segenap bangsa Indonesia dan seluruh tumpah darah Indonesia;

4. Mencerdaskan kehidupan bangsa.

4Kaelan, Pendidikan Pancasila..., h. 140. 
Fungsi Negara Kesatuan Republik Indonesia dapat disimpulkan sebagai berikut, yaitu:

1. Membentuk kelembagaan negara;

2. Membuat Undang-Undang Dasar;

3. Menentukan Anggaran Pendapatan dan Belanja Negara;

4. Membuat Undang-Undang dan peraturan-peraturan umum;

5. Pemeriksaan pertanggungjawaban keuangan negara;

6. Pertimbangan;

7. Pemerintahan menyelenggarakan kemakmuran;

8. Kehakiman;

9. Perencanaan (kegiatan pembangunan negara). ${ }^{5}$

\section{B.2. Dasar Negara Kesatuan Republik Indonesia}

Pancasila sebagai dasar Negara Kesatuan Republik Indonesia (Philosophische Grondslaq). Arbi Sanit menjadikan pancasila sebagai ideologi hanya menurunkan statusnya yang inklusif menjadi ekslusif dalam pertandingan dengan ideologiideologi lainnya seperti saat rezim orde baru. Dengan demikian dasar negara Indonesia adalah Pancasila, yang memiliki nilai refresentatif untuk sebuah negara dengan tingkat heterogenitas suku, agama, ras dan adat istiadat, nilai-nilai yang terkandung dalam Pancasila adalah nilai-nilai universal dan mendasar serta dapat berlaku bagi seluruh warga negara bangsa indonesia tanpa terkecuali.

\section{B.3. Konsepsi Politik Hukum Negara Kesatuan Republik Indonesia}

Politik hukum dengan tujuan negara memiliki hubungan dalam satu sistem hukum nasional harus mencakup beberapa hal-hal sebagai berikut:

1. Tujuan negara yang diidamkan sebagai orientasi politik hukum, termasuk ekskavasi nilai-nilai dasar destinasi negara sebagai pemandu atau pembimbing politik hukum;

2. Sistem hukum nasional yang dibutuhkan untuk mencapai tujuan tersebut serta faktor-faktor yang mempengaruhinya;

3. Perencanaan dan kerangka pikir dalam perumusan kebijakan hukum;

4. Isi hukum nasional dan faktor-faktor yang mempengaruhinya;

5. Pemagaran hukum dengan prolegnas dan judicial review, legislative review. ${ }^{6}$ Pembukaan UUD 1945 alinea ke-IV, menegaskan bahwa tujuan negara harus diarahkan sesuai dengan Pancasila, hal tersebut menggariskan bahwa Pancasila harus sebagai pemandu politik hukum di berbagai bidang kenegaraan. Adapun isi Pancasila adalah sebagai berikut:

1. Dalam sila Ketuhanan Yang Maha Esa, menjadi landasan politik hukum yang berbasis moral agama;

5https:www.tidurbangun.blogspot.com/2014/02/pengertian-fungsi-tujuan-NKRI.html, diakses pada hari Selasa, tanggal 15 Agustus 2017.

${ }_{6}^{6}$ Khairuddin, Irwantoni, Chaidir Nasution...,h. 56. 
2. Dalam Sila Kemanusiaan Yang Adil dan Beradab, menjadi landasan politik hukum yang menghargai serta melindungi hak-hak asasi manusia yang nondiskriminatif;

3. Pada Sila Persatuan Indonesia, menjadi landasan politik hukum dalam mempersatukan seluruh unsur dengan berbagai ikatan primordialnya masing-masing;

4. Dalam sila Kerakyatan Yang Dipimpin Oleh Hikmat Kebijaksanaan Dalam Permusyawaratan/Perwakilan, menjadi landasan politik hukum yang meletakkan kekuasaan dibawah kekuasaan rakyat (demokratis); dan

5. Dalam sila Keadilan Sosial Bagi Seluruh Rakyat Indonesia, menjadi landasan politik hukum dalam kehidupan bermasyarakat yang berkeadilan sosial sehingga mereka yang lemah secara sosial dan ekonomis tidak ditindas oleh mereka yang kuat secara sewenang-wenang.

\section{B.4. Radikalisme Terhadap Negara Kesatuan Republik Indonesia}

Pengamalan Pancasila sebagai ideologi Negara dan falsafah bangsa Indonesia, merupakan keharusan konstitusional. Konteks ini, Pancasila mesti pula di anggap sebagai bagian doktrin luhur seluruh agama, sebab memang Pancasila sudah* berisi nilai-nilai agama. Pancasila memang bukanlah agama dan tidak merupakan sinkretisasi ajaran agama-agama, tetapi Pancasila bukan pula produk pemikiran sekuler yang bertentangan dengan budaya religius Indonesia. Pancasila adalah anak kandung dari budaya Indonesia yang sudah sejak dahulu kala menjadikan agama sebagai etosnya. Mengamalkan nilai-nilai universal agama dengan cara tidak egois pada satu konsep agama dalam konteks kehidupan berbangsa, bernegara dan bermasyarakat secara keindonesiaan adalah pengamalan cara hidup ber-Pancasila.

Menangkal ancaman gerakan yang mengatas namakan agama di Negara Kesatuan Republik Indonesia (NKRI) perlu bagi kita memahami arti ideologi Pancasila. Menurut founding father, Pancasila sebagai ideologi Indonesia merupakan konsep yang utuh dan memiliki tameng yang luar biasa bagi kemakmuran NKRI. Maka dari itu kita harus menanamkan nilai-nilai Pancasila, jiwa sebangsa dan setanah air dan rasa persaudaraan, agar tercipta kekuatan dan kebersamaan di kalangan rakyat Indonesia.

Agama dan negara ialah dua saudara kembar. Agama adalah fondasi, sedangkan negara ialah pengawalnya. Sesuatu yang tidak mempunyai fondasi, bakal runtuh, sementara sesuatu yang tidak mempunyai pengawal, bakal tersiasiakan.

\section{B.5. Politik Hukum Tata Negara Dalam KonsepDan KonteksPancasiladan Kebhinnekaan dalam mempertahankan Negara Kesatuan Republik Indonesia}

Politik hukum tata negara dalam konsepdan konteksPancasila dan Kebhinnekaan dalam mempertahankan Negara Kesatuan Republik Indonesia berkesesuaian dengan teori kebangsaan yang diuraikan oleh Hans Kohn dan Ernest Renan, serta teori geopolitik dari Frederick Ratzel yang mengulas bahwa Pancasila dan Bhinneka Tunggal Ika merupakan Dasar Negara dan Semboyan pemersatu 
bangsa dan merupakan dasar dari pemikiran bangsa dan sendi hukum yang paling dasar dalam kehidupan berbangsa dan bernegara, selain itu semboyan bhinneka tunggal ika merupakan kebudayaan luhur bangsa Indonesia dari zaman nusantara raya. Teori Hukum atau Stufenbou Theory dari Hans Kelsen menempatkan bahwa UUD 1945 sebagai Konstitusi dasar negara pun merupakan penjabaran dari Pancasila dan Bhinneka Tunggal Ika.

Pancasila sering juga disebut way of life. Pancasila dipergunakan sebagai petunjuk kehidupan sehari-hari. Pancasila menjadi penunjuk arah semua kegiatan atau aktifitas hidup dan kehidupan didalam segala bidang. Ini berarti semua tingkah laku dan terbuatan setiap manusia Indonesia harus dijiwai dan merupakan pancaran dari semua sila Pancasila karena Pancasila sebagai weltanschauung selalu merupakan suatu kesatuan, tidak bisa dipisah-pisahkan satu dengan yang lain. Keseluruhan sila merupakan satu kesatuan organis. Pancasila yang harus dihayati adalah Pancasila sebagaimana tercantum dalam Pembukaan Undang-Undang Dasar 1945, antara lain:

1. Jiwa keagamaan. Ini sebagai manifestasi atau perwujudan dari sila ketuhanan yang maha esa;

2. Jiwa yang berperikemanusiaan. Ini sebagai manifestasi/perwujudan dari sila kemanusiaan yang adil dan beradab;

3. Jiwa kebangsaan. Sebagai perwujudan dari sila persatuan Indonesia;

4. Jiwa kerakyatan. Menjadi sebagai manifestasi/perwujudan dari sila kerakyatan yang dipimpin oleh hikmat kebijaksanaan dalam permusyawaratan/perwakilan;

5. Jiwa yang menjunjung tinggi keadilan sosial. Sebagai manifestasi/perwujudan dari sila keadilan sosial bagi seluruh rakyat Indonesi, selalu terpancar dalam segala tingkah laku dan serta sikap hidup seluruh masyarakat Indonesia. ${ }^{7}$

\section{B.6. Kekuatan Negara Kesatuan Republik Indonesia Berdasarkan Pancasila dan Ke-Bhineka Tunggal Ika-an}

Kekuatan NKRI berdasarkan Pancasila dan Ke-bhineka tunggal ika-an,dalam pelaksanaan ketatanageraan kita Indonesia semua unsur harus melaksanakan dan melandaskan segala pergerakannya diatas Pancasila tanpa terkecuali. Toleransi umat beragama merupakan amanat dari Pancasila. Kebebasan dalam berbudaya ialah amanat dari Pancasila. Karena kemajemukan dalam Bingkai NKRI merupakan kristalisasi dari nilai-nilai Pancasila dengan semboyannya Bhineka Tunggal Ika yang artinya berbeda tetapi tetap satu. Sesuai dengan teori kearifan lokal yang disampaikan oleh Von Savigny dan itu harus di tegakkan dalam Bingkai Negara Kesatuan Republik Indonesia, sehingga semangat Pluralisme mewarnai kekuatan bangsa.

7http://lekons-lenterakonstitusi.blogspot.com/2011/12/pentingnya-4-empat-pilar-kebangsaan.html, diakses pada hari Rabu, tanggal 23 Agustus 2017. 


\section{B.7. Radikalisme dan Ancaman Terhadap Keutuhan Negara Kesatuan Republik Indonesia}

Radikalisme di Indonesia menjadi ancaman serius bagi kebhinnekaan tanah air di masa mendatang, akhir-akhir ini radikalisme semakin menguat dan menyasar pelaku sekaligus korbannya di semua tingkatan, bahkan sudah menyasar kalangan generasi muda. Aliran radikal mulai memasuki banyak sektor, diantaranya mulai dari pendidik, pedagang, siswa, dan mereka masuk menembus lintas generasi, lintas profesi. Ada beberapa faktor yang bisa digunakan untuk menjelaskan fenomena radikalisme di kalangan kaum muda, yakni:

1. Dinamika sosial politik di fase awal transisi menuju demokrasi yang membuka struktur kesempatan politik yang baru di tengah tingginya gejolak dan ketidakpastian.

2. Tingginya angka pengangguran di kalangan kaum muda di Indonesia, yang menyebabkan radikalisme mendapat tempat di kalangan generasi muda, serangkaian aksi para pelaku dan simpatisan pendukung baik aktif maupun pasif banyak berasal dari kalangan muda. ${ }^{8}$

Ancaman radikalisme dan terorisme makin mengintai Indonesia, terorisme radikalisme bisa muncul dilatari pemahaman-pemahaman, sebagai berikut:

1. Aliran Khawarij yaitu para teroris yang menganut pemahaman ini di antaranya adalah ISIS, kemudian al Qaidah, Jamaah Islamiyah, dan sejenisnya;

2. Aliran Syiah Rafidhah yaitu keterlibatan kaum syiah rafidhah bisa ditelusuri dari dukungan Iran terhadap pemberontak Hutsi di Yaman, Iran melakukan pelatihan terhadap para teroris di Bahrain bekerja sama dengan organisasi teroris Hizbullah, Lebanon;

3. Aliran Komunisme yaitu doktrin komunisme mengarahkan penganutnya untuk bersikap militan, berani melakukan pemberontakan terhadap penguasa dan menghalalkan segala cara, di antaranya dengan menggunakan aksi teror radikal dalam merebut kekuasaan;

4. Gerakan Separatisme yaitu di Indonesia separatisme seringkali melakukan aksi teror dan radikal kepada penduduk yang setia dengan NKRI. Separatisme dahulu muncul di Aceh dengan Gerakan Aceh Merdeka (GAM). Gerakan separatisme lainnya, seperti Organisasi Papua Merdeka (OPM) di Papua dan Republik Maluku Selatan (RMS) di Maluku;

5. Paham Liberalisme yaitu kaum liberal memiliki andil terhadap aksi terorisme radikalisme dengan membuka katup-katup kebebasan dan demokrasi saat semua orang memiliki kebebasan dalam begara demokrasi, maka semua orang bebas menganut dan menyebarkan pemahaman yang diyakininya.

Terorisme dan Radikalisme serta ancaman terhadap keutuhan Negara Kesatuan Republik Indonesia memiliki kesesuaian dengan teori kearifan lokal (local wisdom) dari Von Savigny yang menyatakan bahwa penguatan wawasan Pancasila dan Bhinneka Tunggal Ika harus dimulai terhadap seluruh masyarakat yang ada di wilayah Indonesia, dengan menguatkan nilai-nilai kearifan lokal, maka bisa

8http://info-bendera-putih.blogspot.co.id/2017/03/bahaya-radikalisme-mengancam-generasi.html, diakses pada hari Minggu, tanggal 3 September 2017. 
mencegah ancaman radikalisme dan ancaman-ancaman terhadap keutuhan bangsa dan negara.

\section{Simpulan}

Politik Hukum Tata Negara Dalam Konsep dan KonteksPancasila dan Kebhinnekaan dalam mempertahankan Negara Kesatuan Republik Indonesia, mencakup pengertian politik hukum adalah kebijakan dasar yang menentukan arah, bentuk, maupun isi hukum yang akan dibentuk. Pancasila yang harus dihayati adalah Pancasila sebagaimana tercantum didalam Pembukaan Undang-Undang Dasar 1945, Bhinneka Tunggal Ika sebagai semboyan pemersatu bangsa dan merupakan dasar dari pemikiran bangsa dan sendi hukum yang paling dasar dalam kehidupan berbangsa dan bernegara. Kekuatan Negara Kesatuan Republik Indonesia Berdasarkan Pancasila dan Ke-Bhineka Tunggal Ika-an, Negara Kesatuan Republik Indonesia sebagai negara yang majemuk, berlandaskan kepada kearifan lokal dalam pelaksanaan ketatanageraan kita Indonesia semua unsur harus melaksanakan dan melandaskan segala pergerakannya diatas Pancasila tanpa terkecuali. Toleransi atas umat beragama adalah amanat dari Pancasila. Radikalisme serta ancaman keutuhan NKRI berkesesuaian dengan teori kearifan lokal (local wisdom) dari Von Savigny yang menyatakan bahwa penguatan wawasan Pancasila dan Bhinneka Tunggal Ika harus dimulai terhadap seluruh masyarakat yang ada di wilayah Indonesia, dengan menguatkan nilai-nilai kearifan lokal, maka bisa mencegah ancaman radikalisme dan ancaman-ancaman terhadap keutuhan bangsa dan negara.

\section{Referensi:}

Ahmad Sukardja, Piagam Madinah dan Undang-Undang Dasar NRI 1945; Kajian Perbandingan Tentang Dasar Hidup Bersama Dalam Masyarakat Yang Majemuk, Sinar Grafika, Jakarta, 2014.

Abdulkadir Muhammad, Hukum Dan Penelitian Hukum, Bandung: Citra Aditya Bakti, 2004.

Heribertus Sutopo, Metode Penelitian Kualitatif, Dasar Teori dan Terapannya Dalam Penelitian, Surakarta, 2002.

Idrus Ruslan, Negara Madani; Aktualisasi nilai-nilai pancasila dalam kehidupan berbangsa dan bernegara, SUKA-Press Universitas Islam Negeri Sunan Kalijaga, Yogyakarta, 2015.

Irfan Idris, Membumikan Deradikalisasi; Soft Approach Model Pembinaan Terorisme Dari Hulu ke Hilir Secara Berkesinambungan, Daulat Press, Jakarta, 2016.

Ismail Sunny, Pergeseran Kekuasaan Eksekutif, Aksara Baru Cet.V, Jakarta, 1983.

Kaelan, Pendidikan Pancasila, Paradigma, Yogyakarta, 2014.

Khairuddin, Irwantoni, Chaidir Nasution, Studi Analisis Politik Hukum Pembentukan Peraturan Perundang-undangan di Indonesia dan Problematikanya, Pusat Penelitian dan Penerbitan Lembaga Penelitian dan Pengabdian Masyarakat IAIN Raden Intan Lampung, Bandar Lampung, 2015.

Komaruddin Hidayat, Wahyu di Langit, Wahyu di Bumi; Doktrin dan Peradaban Islam di Panggung Sejarah, Paramadina, Jakarta, 2003. 
Lintje Anna Marpaung, Revitalisasi Hukum Otonomi Daerah dan Prospektif Kepentingan Daerah, AURA, Bandar Lampung, 2016.

Moh. Mahfud MD, Politik Hukum di Indonesia, PT. Raja Grafindo Persada, Jakarta, 2011.

Miriam Budiarjo, Dasar-Dasar Ilmu Politik, PT. Gramedia Pustaka Utama, Jakarta, 2004.

Nurcholish Madjid, Islam Agama Kemanusiaan; Membangun Tradisi dan Visi Baru Islam Indonesia, Paramadina, Jakarta, 1995.

Padmo Wahjono, Indonesia Negara Berdasarkan Atas Hukum, Ghalia Indonesia, Jakarta, 1986.

Poerwadaminta, Kamus Besar Bahasa Indonesia, Ghalia Indonesia, Jakarta, 1976.

Ramlan Surbakti, Memahami Ilmu Politik, PT. Gramedia Pustaka Utama, Jakarta, 1992.

RM.A.B Kusuma, Lahirnya Undang-Undang Dasar 1945, Fakultas Hukum UI, Jakarta, 2004.

Undang-Undang Dasar Negara Republik Indonesia Tahun 1945;

Undang-Undang Nomor 12 Tahun 2011 tentang Hierarki Peraturan Perundangundangan.

Peraturan Pemerintah Pengganti Undang-Undang (Perppu) No. 2 Tahun 2017 tentang Perubahan Atas Undang-Undang (UU) Nomor 17 Tahun 2013 tentang Organisasi Kemasyarakatan.

Kamus Hukum Indonesia, Indonesian Law Dictionary

I Nyoman Pursika, 2009, Kajian Analitik Terhadap Semboyan "Bhinneka Tunggal Ika", Jurnal Pendidikan dan Pengajaran, Jilid 2 Nomor 1, Jakarta

http: www.kemendagri.go.id/keppres_no.24_th_2016.pdf,

http: www.kemendagri.go.id/perppu_no.2_th_2017.pdf,

http:/ / yudaeka793.blogspot.co.id/2014/06/ piramida-hukum-nasionalindonesia.html,

https:www.markijar.com/ / pengertian-fungsi-dan-tujuan-NKRI.html,

https:www.tidurbangun.blogspot.com/2014/02/pengertian-fungsi-tujuan-

NKRI.html

http:/ / lekons-lenterakonstitusi.blogspot.com/2011/12/ pentingnya-4-empat-pilarkebangsaan.html,

https:www/pkn-ips.blogspot.com/2014/10/negara-kesatuan-republik-indonesiankri.html,

http:/ / politik.rmol.co/read/2017/04/23/288737/Membumikan-Pancasila,Menjaga-NKRI-,

http:/ / fhukum.unpatti.ac.id/htn-han/46-bhineka-tunggal-ika-dalam-bingkainegara-kesatuan-republik-indonesia,

https:/ / kewarganegaraanku.wordpress.com/2011/11/12/proses-terjadinya-nkri/, www.bukupedia.net/2016/08/proses-terbentuknya-nkri-negara-kesatuan-republikindonesia-secara-singkat.html.

http:/ / artonang.blogspot.co.id/2015/10/pengertian-fungsi-dan-kedudukan-uud1945.html,

http:// komunitasgurupkn.blogspot.com/2014/08/arti-penting-uud-1945-bagibangsa-dan.html, 
http:/ /info-bendera-putih.blogspot.co.id/2017/06/makalah-radikalismepengertian-konsep.html,

http:/ / ayunurulsarah.blogspot.co.id/2015/12/ancaman-fundamentalismeterhadap-nkri.html,

http:/ / www.beritasatu.com/politik/398279-menjaga-nkri-dari-ancamanradikalisme-dan-terorisme-adalah-pahlawan-sejati.html,

http:/ / info-bendera-putih.blogspot.co.id/2017/03/bahaya-radikalismemengancam-generasi.html,

http:/ / nasional.kompas.com/read/2016/11/24/08520891/ancaman.radikalisme, http:// www.tribunnews.com/nasional/2017/08/06/kakorbinmas-polri-terorismedisebar-di-indonesia-karena-isis-terdesak-di-suriah-dan-irak, 